Technological University Dublin

DỨBLIN

ARROW@TU Dublin

2005-01-01

\title{
Correlation of Spectroscopic and Biochemical Assays Postionising Radiation Exposure in Human Skin Cell Analogues
}

Aidan D. Meade

Technological University Dublin, aidan.meade@tudublin.ie

Hugh J. Byrne

Technological University Dublin, hugh.byrne@tudublin.ie

Fiona M. Lyng

Technological University Dublin, fiona.lyng@tudublin.ie

Follow this and additional works at: https://arrow.tudublin.ie/radcon

Part of the Physics Commons

\section{Recommended Citation}

Meade, A., Byrne, H. \& Lyng, F. (2005). Correlation of spectroscopic and biochemical assays postionising radiation exposure in human skin cell analogues. Proceedings of Optolreland 2005. SPIE. vol. 5826, pg.

397. doi: $10.1117 / 12.611450$

This Conference Paper is brought to you for free and open access by the Radiation and Environmental Science Centre at ARROW@TU Dublin. It has been accepted for inclusion in Conference papers by an authorized administrator of ARROW@TU Dublin. For more information, please contact arrow.admin@tudublin.ie, aisling.coyne@tudublin.ie,gerard.connolly@tudublin.ie.

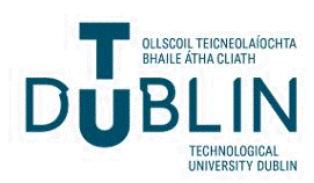


Proceedings of OptoIreland 2005, H.J. Byrne, E. Lewis, B. D. MacCraith, E. McGlynn, J.A. McLaughlin, G.D. O'Sullivan, A.G. Ryder, J.E. Walsh eds., SPIE vol 5826, 397 (2005)

\title{
Correlation of spectroscopic and biochemical assays post- ionising radiation exposure in human skin cell analogues
}

\author{
A.D. Meade ${ }^{* 1,3}$, H.J. Byrne ${ }^{2}$, F.M. Lyng ${ }^{2,3}$ \\ 1. School of Physics, Dublin Institute of Technology, Dublin 8, Ireland; \\ 2. Focas Institute, Dublin Institute of Technology, Dublin 8, Ireland; \\ 3. Radiation and Environmental Science Centre (RESC), Dublin Institute of Technology, Dublin \\ 8, Ireland;
}

\begin{abstract}
Raman spectroscopy, as an evaluation of the products of ionising radiation exposure in biological systems, has been utilised mainly in the evaluation of the impact of exposure in tissue, cellular constituents and live animals. It has also been recently demonstrated that Raman spectroscopy can demonstrate key spectroscopic changes in the live cell associated with significant apoptotic and necrotic chemical damage. The present preliminary work utilises Raman spectroscopy at $514.5 \mathrm{~nm}$ to evaluate the results of exposure to $\gamma$-rays in $\mathrm{HaCaT}$ cells from a Co-60 therapy source, in tandem with other biological assays. The results demonstrate that a number of spectral changes may be correlated with changes in the cell also identified in parallel biochemical assays.
\end{abstract}

Keywords: Raman spectroscopy, $\mathrm{HaCaT}$ keratinocyte, Co-60 gamma irradiation, $\mathrm{AB}$ assays

\section{INTRODUCTION}

Vibrational spectroscopy, as a tool for the characterisation of tissue and other biological specimens, has undergone very significant expansion over the past decade ${ }^{1,2,3}$. Both FTIR and Raman spectroscopy have seen new applications as a tool for the analysis of the morphological structure of tissue and cellular media and also for the analysis of cellular function in live samples s, $^{3,5,5,6,7,8}$.

This approach to the characterisation of biological specimens is particularly useful given its nondestructive nature. Vibrational spectroscopy characterises the structure and conformation of biological macromolecules within a biological sample. This potentially allows the simultaneous assay of a variety of molecular specimens. Raman spectroscopy is particularly suited to this application given the absence of an obscuring water-associated signature in the spectra of biological samples. Raman spectroscopy is based on the inelastic scattering of incident light photons by molecular vibrations that are 'Raman active' within a sample. Cellular spectra are composed of combinations of the individual spectra of each of the biological macromolecules (amino acid, protein, lipid, nucleic acids etc.) that compose the cell. Changes in structure or conformation of these samples are indicative of changes in structure or function of the biological sample.

Raman spectroscopy has previously been applied in a limited number of studies as a tool for the characterisation of the cellular damage induced by ionising radiation. These studies investigated the damage induced by proton irradiation of mouse and swine tissue ${ }^{11}, \gamma\left({ }^{137} \mathrm{Cs}\right)$ irradiation of liposomes and cell membrane ${ }^{12-14}$ and $\gamma(\mathrm{Co}-60)$ irradiation of cerebral tissue in mice ${ }^{15}$. To date no study has employed Raman spectroscopy as an assay of specific radiation induced damage and as a progression of this damage with respect to the functionality of living cells. The present preliminary study demonstrates the potential of Raman spectroscopy as an assay tool for $\gamma$-irradiation damage in a human keratinocyte cell line ( $\mathrm{HaCaT}$ ) with respect to assays of cellular metabolism. 


\subsection{Raman spectroscopy}

\section{MATERIALS AND METHODS}

A bench-top Instruments S.A. Labram 1B spectrometer was used throughout these measurements (shown in figure 1), fed by an Argon-Ion laser operating at $514.5 \mathrm{~nm}$. A x100 objective was employed which gave a spatial resolution of $\sim 1 \mu \mathrm{m}$ at the sample. The laser power at the objective focus was found to be $4 \mathrm{MW}$. The Labram imaging system is a fully confocal Raman microscope system, including a stigmatic spectrometer with two motorised gratings, of which the 1800 lines/mm grating was used. The resolution of the system operating with the 1800 lines $/ \mathrm{mm}$ was $1.65 \mathrm{~cm}^{-1} / \mathrm{pixel}$. The detector system used was a Peltier cooled, 16-bit dynamic range CCD detector with $1024 \times 256$ pixels. The scattered Raman signal was integrated for 120 seconds over the spectral range from 400 to 1888 $\mathrm{cm}^{-1}$ with respect to the excitation frequency.

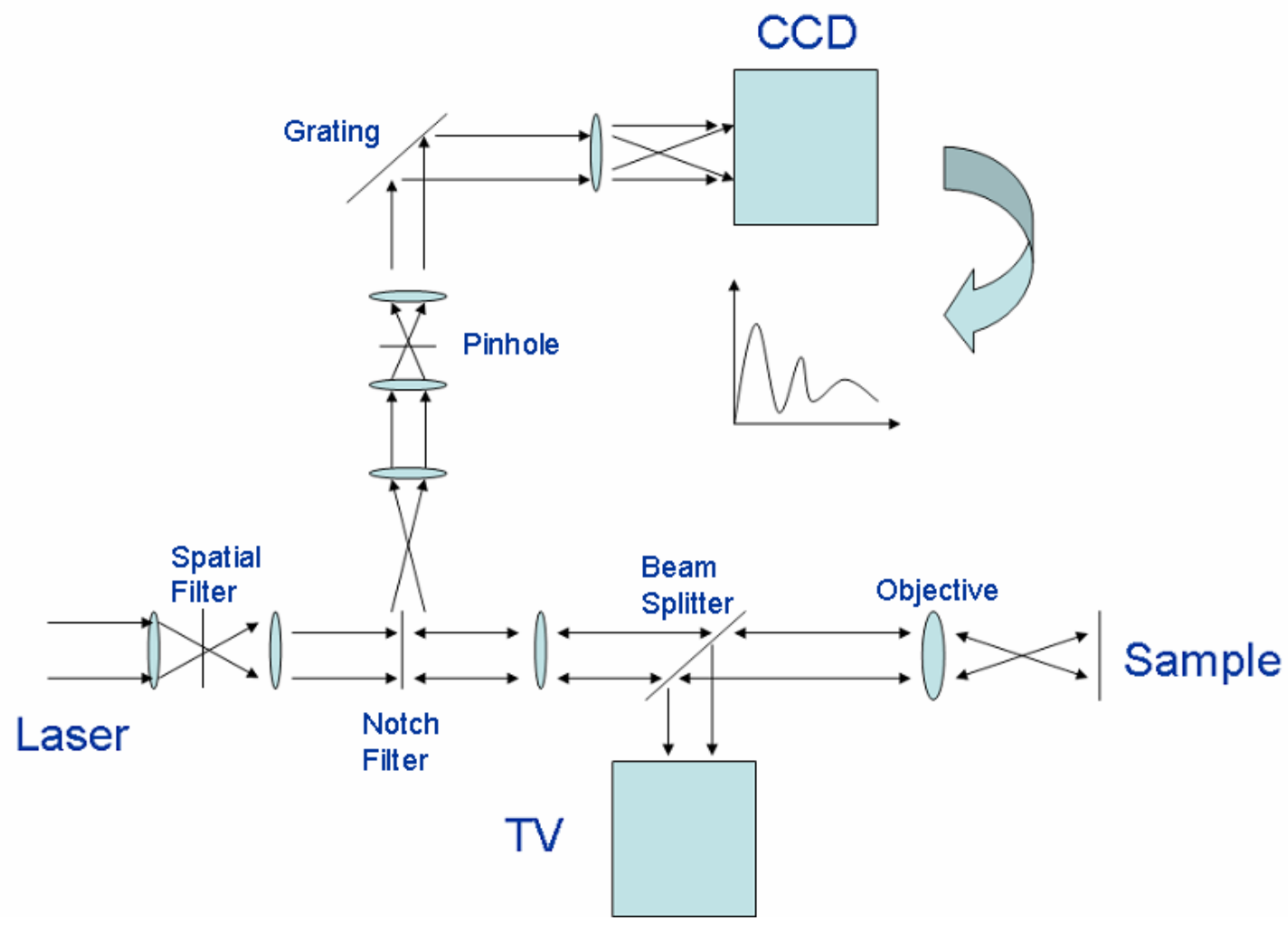

Fig. 1 Schematic layout of Labram Raman Spectrometer.

\subsection{Cell Culture, Preparation and Irradiation}

The human keratinocyte cell $(\mathrm{HaCaT})$ line was used from existing laboratory stocks in all the experiments. All cells were from the same passage from a single sample. The cells were cultured at $37^{\circ} \mathrm{C}$ in a $5 \% \mathrm{CO}_{2}$ environment in Dulbecco's Modified Eagle's Medium (DMEM, Gibco/BRL) containing $10 \%$ FCS, $1 \%$ L-glutamine, $1 \%$ penicillin-streptomycin and $0.2 \%$ hydrocortisone. Cells were removed from their culture flasks using a 50-50 trypsin/versene mixture. Three independent samples of cells were seeded on circular glass substrates (radius $2 \mathrm{~cm}$ ) 36 hours prior to irradiation, at approximately $1 \times 10^{5}$ cells per substrate, in order to produce a minimum of a 50-60\% confluent monolayer on the substrates at all times post irradiation. The same three independent samples of cells were also seeded, at concentrations of $5 \times 10^{3}$ and $1 \times 10^{4}$ cells per well, on 96-well microplates for the purposes of biochemical assays. These concentrations were shown to produce $70-90 \%$ confluent monolayers in the culture wells at all times post-irradiation. Cells were washed and fixed in formalin at 6 and 12 hours post-irradiation.

All samples were irradiated by a Co-60 $\gamma$-ray radiotherapy source. Glass-seeded samples and 96-well plates were irradiated to doses of $5 \mathrm{mGy}, 20 \mathrm{mGy}, 50 \mathrm{mGy}, 200 \mathrm{mGy}, 500 \mathrm{mGy}, 750 \mathrm{mGy}, 1 \mathrm{~Gy}, 2.5$ Gy and $5 \mathrm{~Gy}$, and a control sample was sham-irradiated for comparison purposes. For the purposes of assessing the susceptibility of $\mathrm{HaCaT}$ cells to $\gamma$-irradiation, a clonogenic assay was also performed. A known number of cells (300-400) from three independent samples were attached to $50 \mathrm{ml}$ flasks and 
irradiated to $5 \mathrm{mGy}, 500 \mathrm{mGy}$ and $5 \mathrm{~Gy}$, along with a control sample. The number of colonies formed 12 days post-irradiation within each flask were counted manually after staining with Carbol-Fuschin. The mean number of colonies formed was then plotted against dose.

\subsection{Biochemical Assays}

Alamar Blue (AB) is an assay of cellular mitochondrial activity. Alamar Blue is taken up in its

oxidized (blue) form by the cell and reduced by phosphorylation within the cell ${ }^{15,16}$. Its reduced form (pink) is then allowed to leak out of the cell $^{16,17}$. The reduced form of the $A B$ may be assayed spectrofluorometrically by excitation at $530-560 \mathrm{~nm}$ and measurement at $590 \mathrm{~nm}$. In this study $100 \mu \mathrm{l}$ of a $10 \%$ concentration Alamar Blue sample was added to PBS-washed (Phosphate Buffered Saline) wells of a 96-well plate 30 mins before the spectrofluorometric assay (this time was found by a previous range-finding study). It was not removed prior to the spectrofluorometric assay. The Alamar Blue working-solution was created by adding pure Alamar Blue to DMEM medium $(\mathrm{pH}=6.9)$ that did not contain the phenol red indicator commonly present in DMEM, as this interferes with its fluorescence at $535 \mathrm{~nm}^{15,16}$. In addition to the assay wells containing cells, other empty wells were infused with $\mathrm{AB}$ and their fluorescence taken as a measurement of background, which was subsequently subtracted from fluorescence measured from the assay wells.

Fluorescence as fluorescent units was quantified with a microplate reader (TECAN GENios, Grodig, Austria), for separate wells assigned for use for assay by $\mathrm{AB}$ and DCF-DA. Nine wells were assayed for $\mathrm{AB}$ fluorescent at each time point, with three wells assayed for DCF-DA at each time point.

\subsection{Spectral Analysis}

All Raman spectra acquired contained contributions from both sample fluorescence and the glass substrate. These contributions were removed manually from all spectra. Spectra were acquired from 20 random locations on the surface of each sample. Final spectra for a single sample were taken as the average of the 20 spectra for a single sample to remove variation associated with the location of the laser spot within the sample and cell-to-cell biological variation. Final spectra at each dose point were taken as the mean of the spectra for each of the three independent biological samples.

Peak assignments within the spectra were assigned from the data in Table 1. This data has been taken from a number of publications that list assignments for biological samples.

\begin{tabular}{|c|c|}
\hline Wavenumber $\left(\mathrm{cm}^{-1}\right)$ & Assignment \\
\hline 3070 & Amide $\mathrm{B}(\mathrm{CNH}$ bend $)$ \\
\hline 2960 & $\mathrm{CH}_{3}$ stretch \\
\hline 2936 & $\mathrm{CH}_{3}$ stretch \\
\hline 2886 & $\mathrm{CH}_{2}$ stretch \\
\hline 2854 & $\mathrm{CH}_{2}$ stretch \\
\hline 2739 & $\mathrm{CH}$ stretch \\
\hline 1736 & $\mathrm{C}=\mathrm{O}$ stretch \\
\hline 1667 & Amide I (protein) \\
\hline 1657 & $\begin{array}{l}\mathrm{C}=\mathrm{C} \text { stretch (lipids), } \\
\text { Amide I ( } \alpha \text {-helix, protein) }\end{array}$ \\
\hline 1611 & Tyr (aromatics) \\
\hline 1566 & $\begin{array}{l}\text { Phe, Trp (phenyl, } \\
\text { aromatics) }\end{array}$ \\
\hline 1509 & $\mathrm{C}=\mathrm{C}$ stretch (aromatics) \\
\hline 1452 & $\mathrm{CH}_{2}$ stretch (lipids) \\
\hline 1439 & $\mathrm{CH}_{2}$ def. \\
\hline 1420 & $\begin{array}{l}\mathrm{CH}_{3} \text { asymmetric stretch } \\
\text { (lipids, aromatics) }\end{array}$ \\
\hline 1382 & $\mathrm{COO}^{-}$symmetric stretch \\
\hline 1367 & $\mathrm{CH}_{3}$ symmetric stretch \\
\hline 1336 & $\begin{array}{l}\text { Adenine, Phenylalanine, } \\
\mathrm{CH} \text { deformation }\end{array}$ \\
\hline 1304 & $\begin{array}{l}\text { Lipids } \mathrm{CH}_{2} \text { twist, protein } \\
\text { amide III band, adenine, } \\
\text { cytosine }\end{array}$ \\
\hline 1267 & $\begin{array}{l}\text { Amide III ( } \alpha \text {-helix, } \\
\text { protein) }\end{array}$ \\
\hline 1250 & $\begin{array}{l}\text { Amide III ( } \beta \text {-sheet, } \\
\text { protein) }\end{array}$ \\
\hline 1206 & C-C stretch, C-H bend \\
\hline 1165 & $\mathrm{C}-\mathrm{O}$ stretch, $\mathrm{COH}$ bend \\
\hline 1130 & $\mathrm{C}-\mathrm{C}$ asymmetric stretch \\
\hline 1100,1081 & $\begin{array}{l}\mathrm{PO}_{2}^{-} \text {symmetric stretch } \\
\text { (nucleic acids) }\end{array}$ \\
\hline 1065 & Chain C-C \\
\hline 1003 & $\begin{array}{l}\text { Phenylalanine (ring- } \\
\text { breathing) }\end{array}$ \\
\hline 967 & $\begin{array}{l}\mathrm{C}-\mathrm{C} \text { and } \mathrm{C}-\mathrm{N} \text { stretch } \\
\mathrm{PO}_{3}{ }^{2-} \text { stretch (DNA) }\end{array}$ \\
\hline 957 & $\begin{array}{l}\mathrm{CH}_{3} \text { deformation (lipid, } \\
\text { protein) }\end{array}$ \\
\hline 936 & $\mathrm{C}$-C residue $\alpha$-helix \\
\hline 921 & $\mathrm{C}-\mathrm{C}$ stretch proline \\
\hline 898 & $\mathrm{C}-\mathrm{C}$ stretch residue \\
\hline 853 & $\begin{array}{l}\text { Ring breathing } \mathrm{Tyr}-\mathrm{C}-\mathrm{C} \\
\text { stretch proline }\end{array}$ \\
\hline 828 & $\begin{array}{l}\text { Out of plane breathing Tyr } \\
\mathrm{PO}_{2}^{-} \text {asymmetric stretch } \\
\text { DNA }\end{array}$ \\
\hline 786 & $\begin{array}{l}\text { DNA - RNA }\left(\mathrm{PO}_{2}^{-}\right) \\
\text {symmetric stretching }\end{array}$ \\
\hline 746 & Thymine \\
\hline 727 & Adenine \\
\hline 661 & Cysteine C-S \\
\hline $512-545$ & Cysteine C-S \\
\hline
\end{tabular}

Table 1. Peak assignments derived from Krishna et $\mathrm{al}^{7}$, Nijssen et $\mathrm{al}^{8}$, Synytsya et $\mathrm{al}^{11}$, and Gremlich and Yan ${ }^{20}$. 


\subsection{Clonogenic Assay}

\section{RESULTS AND DISCUSSION}

The results of the clonogenic assay are presented in figure 2. This demonstrates that there is clearly no statistically significant loss of reproductive capacity in $\mathrm{HaCaT}$ cells at doses up to $0.5 \mathrm{~Gy}$, with a significant degree of loss of function in this regard at $5 \mathrm{~Gy}$. While this focuses on one of the many functional aspects of the cell, it does demonstrate that the HaCaT cell maintains a high level of functionality post-ionising radiation exposure in comparison to other cell types ${ }^{17}$.

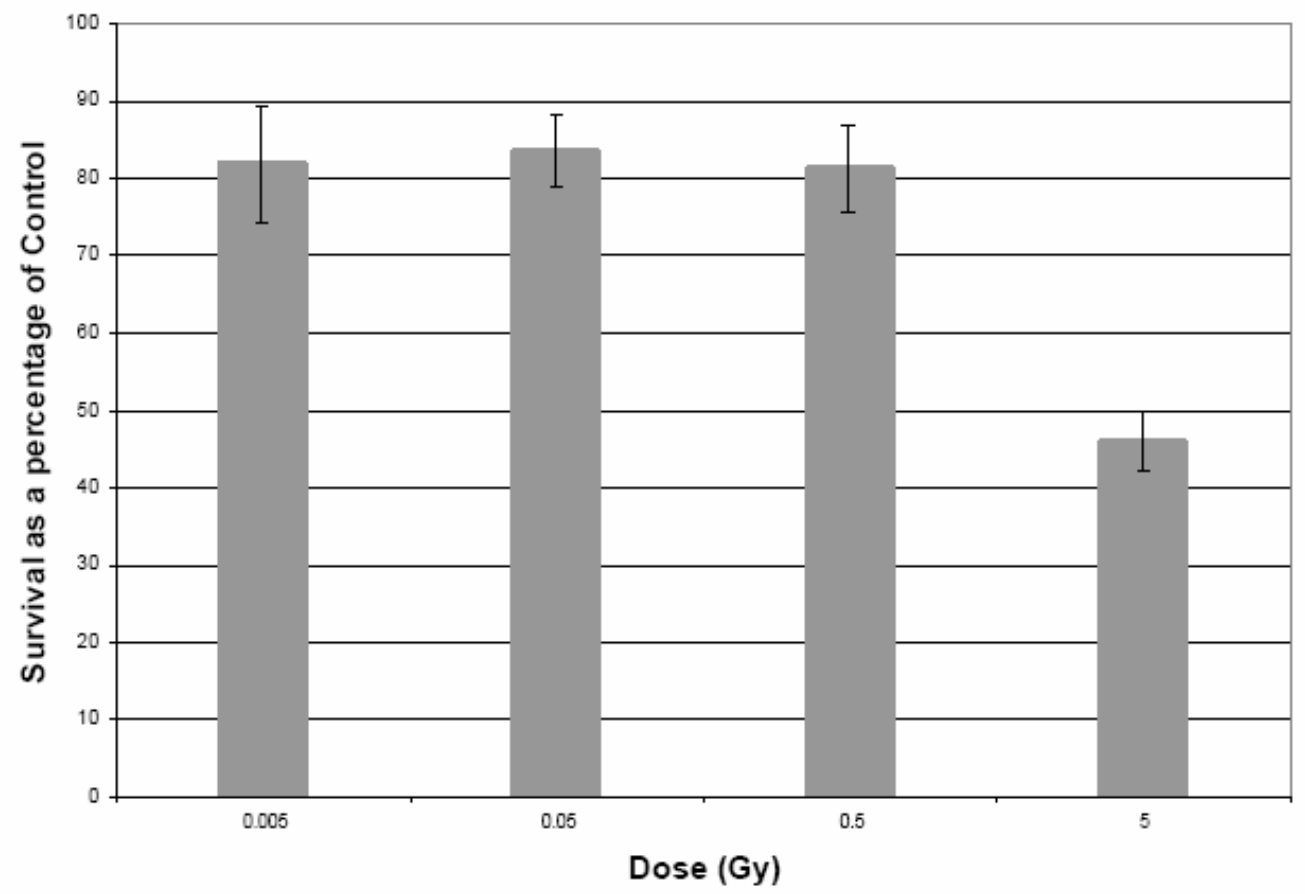

Fig. 2. Clonogenic assay result depicting loss of reproductive ability in $\mathrm{HaCaT}$ cells with dose.

\subsection{Biochemical Assays}

From a biological perspective the outcome of the $\mathrm{AB}$ assay proved to be interesting. The profile of $\mathrm{AB}$ fluorescence with time p.i. (post-irradiation) and dose is depicted in figure 3. This data indicates that there is an unexpected and consistent increase in metabolism at high doses within HaCaT cells postirradiation, an effect which is not seen in control cells, nor in those irradiated to substantially lower doses. This profile of response is consistent with time post-irradiation, while there is, in the present sample, no statistically significant decrease in overall response with time post-irradiation. This particular result is of note as it has not been observed previously, and is an unexpected one. It is possible that this is due to an increase in metabolism as part of a repair process in the cell post irradiation, although present literature indicates that it should not occur. It is clear at leastfrom the clonogenic assay results that the HaCaT cell is robust in the presence of ionising radiation. The elucidation of the trigger of increased metabolism and mechanisms of this repair, if any, will be the subject of further investigations. 


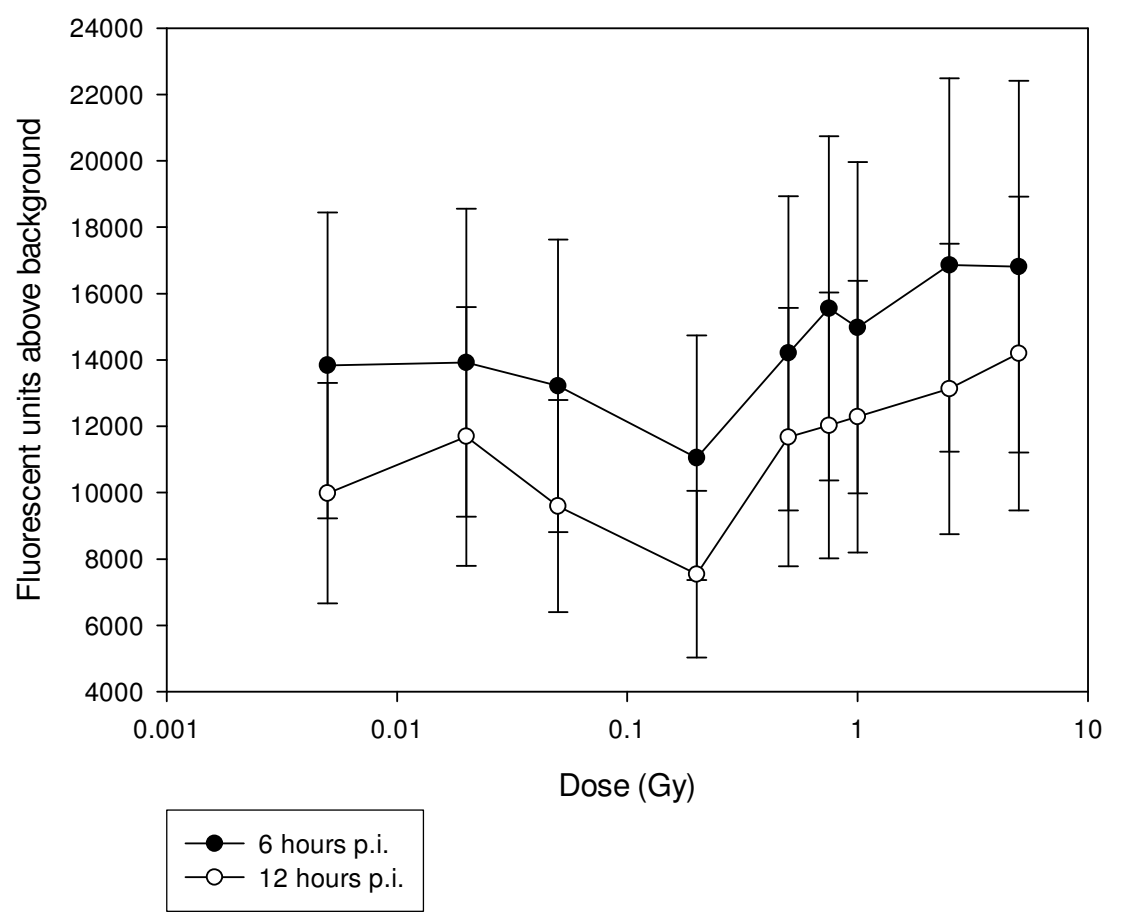

Fig. 3. AB fluorescence with time post-irradiation and dose.

\subsection{Raman Spectral Measurements}

The typical profile of the Raman spectra observed in the un-irradiated HaCaT cell is depicted in figure $4 \mathrm{a}$ and figure $4 \mathrm{~b}$. In figure $4 \mathrm{~b}$ the observed spectral peaks in the region above $2400 \mathrm{~cm}^{-1}$ are shown. The main features are associated with vibrations of groups within lipid molecules (C-H stretch at 2739 $\mathrm{cm}^{-1}$ and $\mathrm{CH}_{2} / \mathrm{CH}_{3}$ stretch from 2870 to $2975 \mathrm{~cm}^{-1}$ ). There is limited spectral information in this portion of the spectrum, and indeed little change in either shape or intensity of these features was observed between control and irradiated samples.

Raman spectra of $\mathrm{HaCaT}$ cells are characterised by strong Amide I $\left(1664 \mathrm{~cm}^{-1}\right), \mathrm{CH}_{2}$ and $\mathrm{CH}_{3}$ bend $\left(1450 \mathrm{~cm}^{-1}\right)$, an intense phenyl ring breathing peak $\left(1003 \mathrm{~cm}^{-1}\right)$ and a composite band prior to this from 1188 to $1412 \mathrm{~cm}^{-1}$ including Amide III, C-C and C-O stretch, amino acid and lipid assignments. In the fingerprint region vibrations assigned to DNA/RNA $\left(780\right.$ and $\left.830 \mathrm{~cm}^{-1}\right)$, cysteine bonds $(665$ and a broad peak from $545-470 \mathrm{~cm}^{-1}$ ). This profile is consistent with the spectral profile observed previously for normal human skin tissue ${ }^{8,11}$.

During the performance of the spectral measurements, no spectral changes indicative of sample degradation were observed as have been reported previously in experiments using the $514.5 \mathrm{~nm}$ laser line $e^{10,18,19}$. The only notable and consistent change in the spectra during measurement was a general decrease in baseline with duration of exposure to the laser, indicating a decrease in fluorescence in the sample with time.

Fixation of cells and tissue with formalin chemically freezes the cell in time. This process also causes the formation of N-N cross-links between protein amide terminals and side chains. This should consequently alter the amide bands within cellular spectra if fixation alters the freedom of amide centres to vibrate. Currently no conclusive evidence exists regarding the effect of formalin fixation on the Raman spectra of biological samples, particularly so for cellular samples. However, it is known ${ }^{7}$ that contamination of samples by formalin produces peaks at $1041 \mathrm{~cm}^{-1}$ and $1492 \mathrm{~cm}^{-1}$. No such evidence of contamination by formalin was seen in the spectra reported here ${ }^{22}$. 


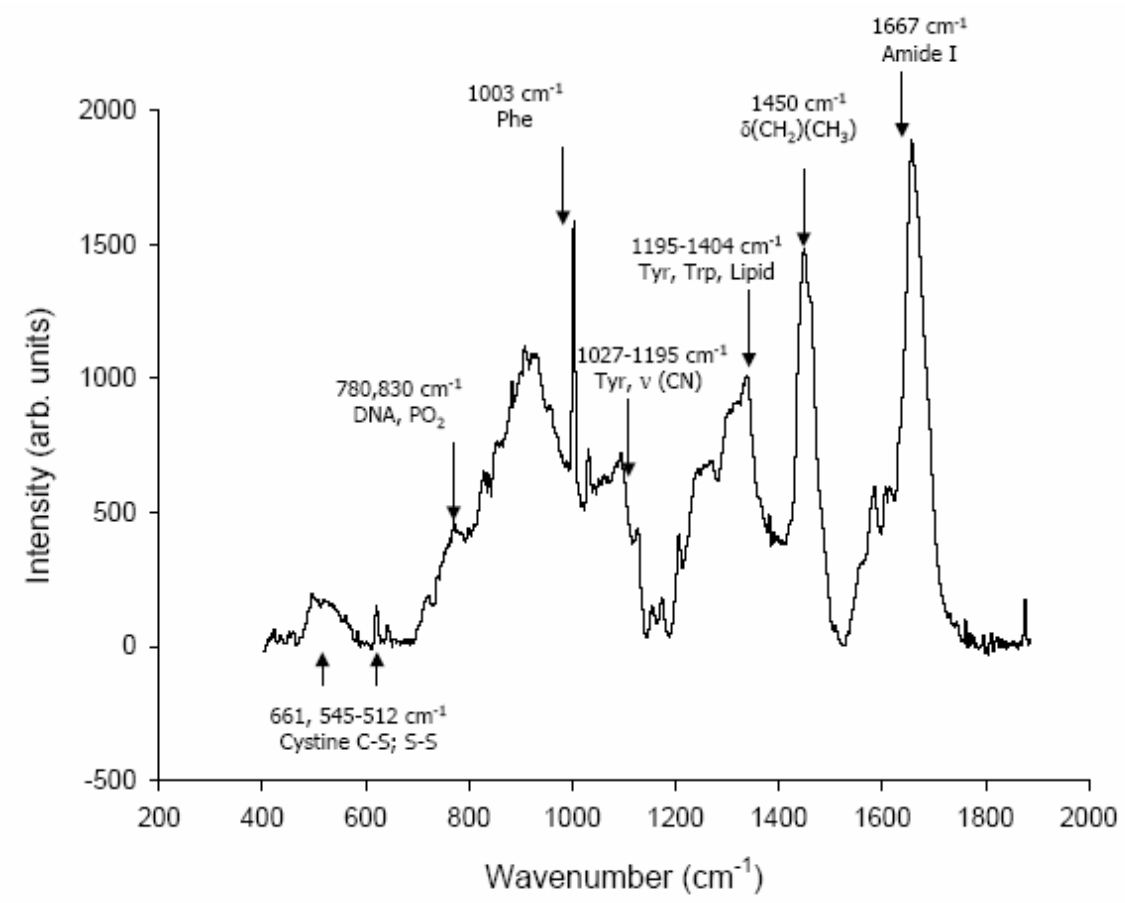

Fig. 4a. Observed Raman spectrum in typical control sample; 400 to $1888 \mathrm{~cm}^{-1}$.

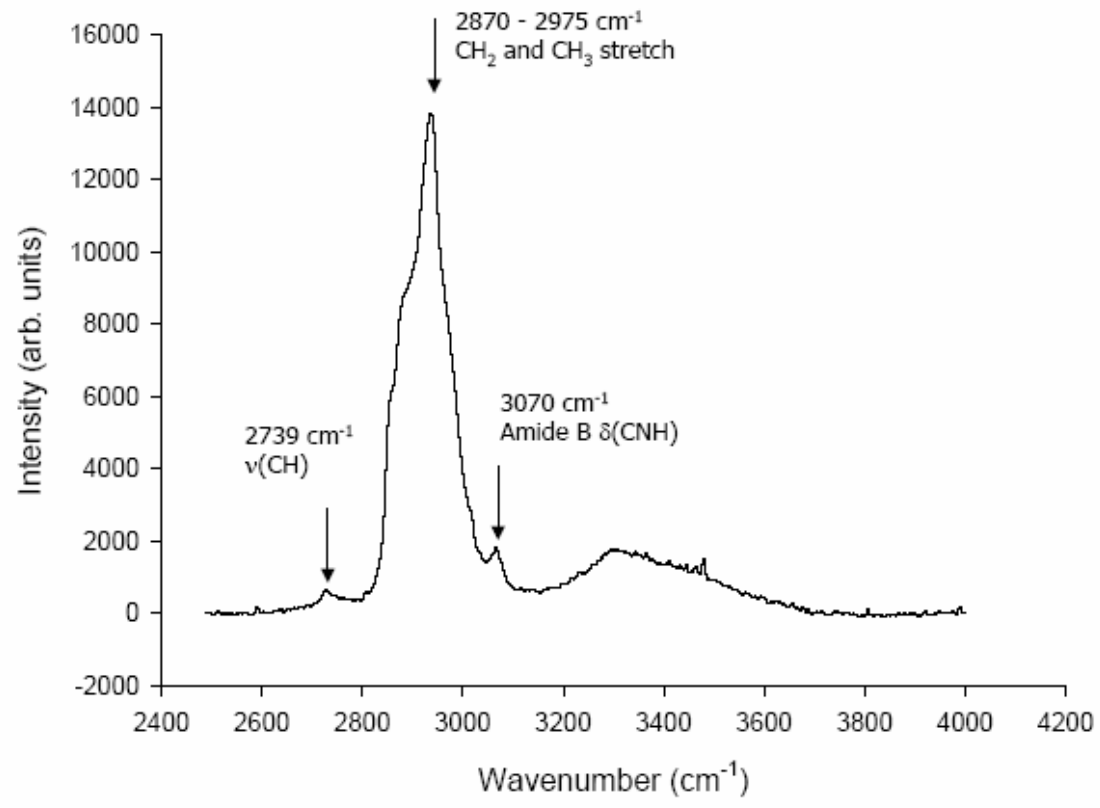

Fig. 4b. Observed Raman spectrum in typical control sample.

The spectra of the irradiated samples (figure 5 and 6) display no peak shifts but generalised peak intensity variations relative to the control sample. This effect is consistent with time post-irradiation. Consistent peak intensity changes occur across all wavenumbers. Of particular interest is the apparent increase in the amide band intensity with lower doses and its subsequent decrease at higher doses. This variation has been quantified with respect to the control sample in the Amide I band, and is displayed in figure 7. The error bars display the standard errors on the peak intensities across all samples. 


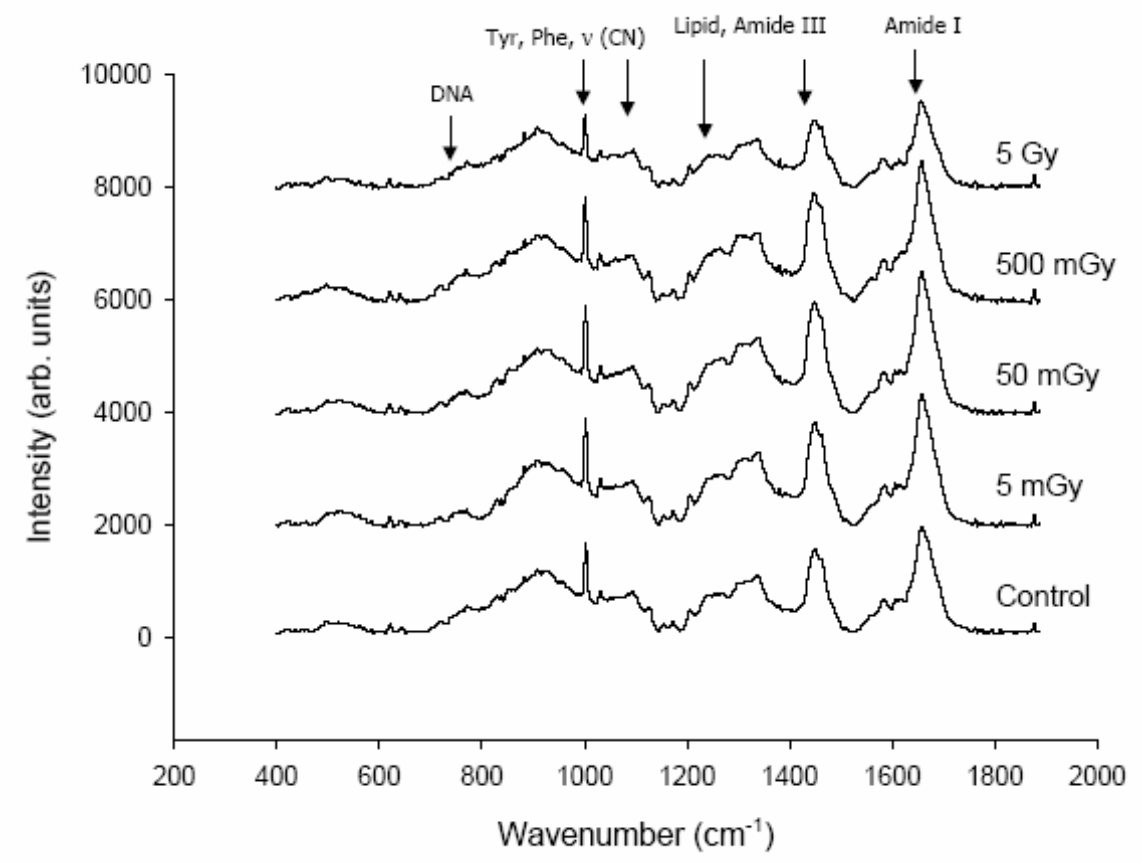

Fig. 5. Observed Raman spectra at 6 hours p.i.

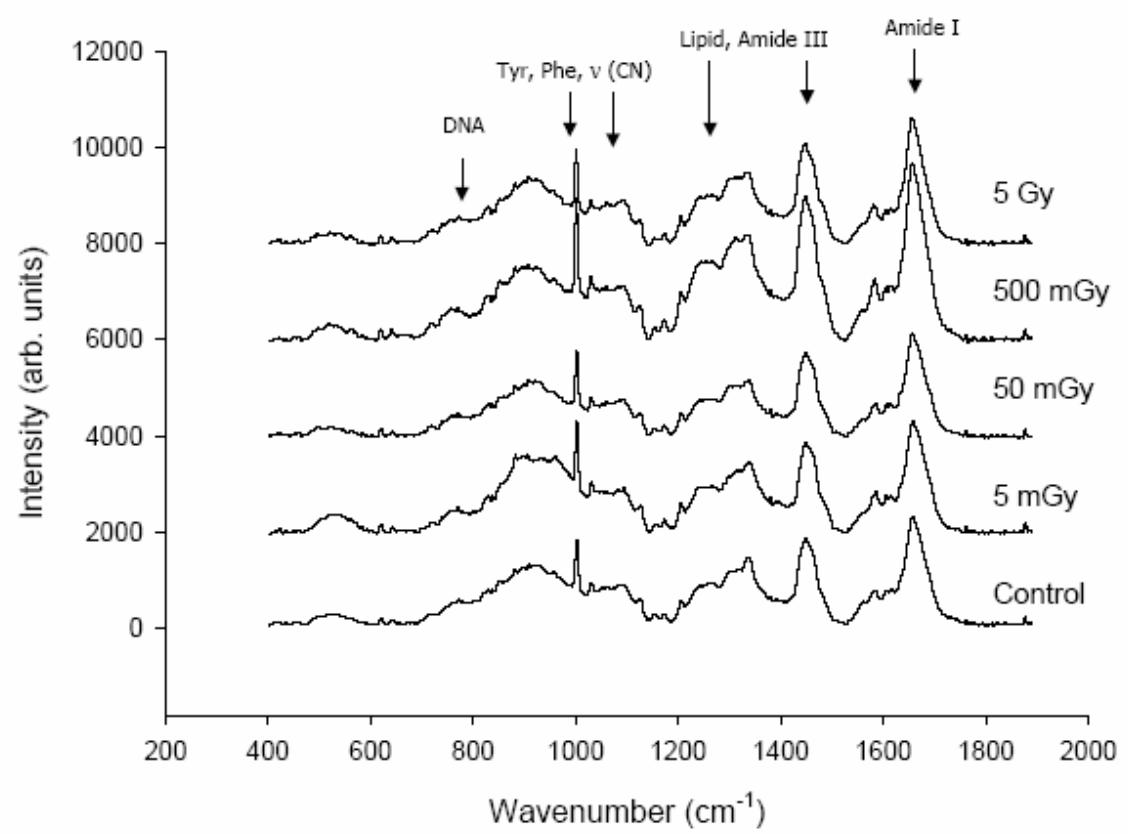

Fig. 6. Observed Raman spectra at 12 hours p.i. 


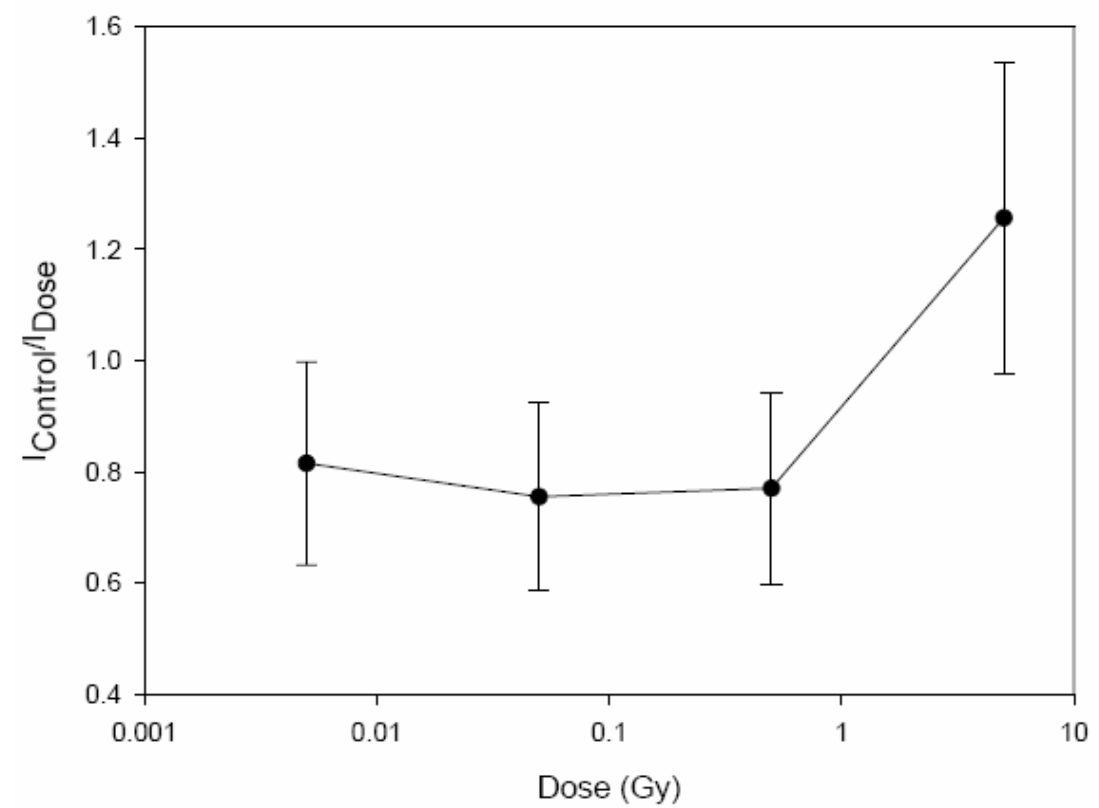

Fig. 7. Observed variation in Amide I band intensity with respect to control sample at 6 hours p.i.

There is a marked similarity in the variation in Amide I band intensity and the variation in $\mathrm{AB}$ fluorescence seen with dose in figure 3 . If there is indeed a variation in the metabolism within the cell with dose p.i. as a consequence of repair mechanisms, then this should be expressed in an increase in protein concentration, which is exemplified by the data in figure 7 . The most notable changes are within the region between 0.5 and $5 \mathrm{~Gy}$ consistent with results of figures 2 and 3 . This postulates that the Raman spectrum of the cellular samples might have opportunities for use as an assay of cellular function post-irradiation. Further studies are required if this tentative and preliminary result is to be confirmed.

\section{CONCLUSION}

The preliminary results in this report postulate opportunities for applications of Raman spectroscopy as a biological assay tool in cells post-irradiation. More doses Substantial confirmatory work still remains to be carried out in order to demonstrate similar effects both in other cellular systems and also with respect to other assays of cellular function and response to irradiation.

\section{ACKNOWLEDGEMENTS}

Focas was funded under the National Development Plan 2000-2006 with assistance from the European Regional Development Fund. This research is funded by the DIT TERS programme.

\section{REFERENCES}

1. G.J. Puppels, F.F.M. de Grul, C. Otto, J. Greve, M. Robert-Nicoud, D.J. Arndt-Jovin and T.M. Jovin, Studying single living cells and chromosomes by confocal Raman microspectroscopy, Nature, 301-303 (1990).

2. M.A. Cohenford, B. Rigas, Cytologically normal cells from neoplastic cervical samples display extensive structural abnormalities on IR spectroscopy: Implications for tumor biology, Proc. Natl. Acad. Sci. USA, 95, pp. 15327-15332, 1998.

3. H.Y.N. Holman, M.C. Martin, E.A. Blakely, K. Bjornstad, W.R. McKinney, IR spectroscopic characteristics of cell cycle and cell death probed by synchrotron radiation based fourier transform IR spectromicroscopy, Biopolymers (Biospectroscopy), 57, 329-335 (2000).

4. I. Notingher, I. Bisson, A.E. Bishop, W.L. Randle, J. M. Polak and L.L. Hench, In situ monitoring of mRNA translation in embryonic stem cells during differentiation in vitro, Anal. Chem., 76, 3185-3193, 2004. 
5. C. Krafft, T. Knetsche, A. Siegner, R.H.W. Funk, R. Salzer, Mapping of cells by near infrared Raman microspectroscopy, Vibrational Spectroscopy, 32, 75-83 (2003).

6. G.J.Puppels, H.S.P. Garritsen, G.M.J. Segers-Nolten, F.F.M.de Mul, J. Greve, Raman microspectroscopic approach to the study of human granulocytes, Biophysical Journal, 60, 1046-1056 (1991).

7. C. Murali Krishna, G.D. Sockalinum, J. Kurien, L. Rao, L. Venteo, M. Pluot, M. Manfait, V.B. Kartha, Micro-raman spectroscopy for optical pathology of oral squamous cell carcinoma, Applied Spectroscopy, 58, 9 (2004).

8. A. Nijssen, T.C. Bakker Schut, F. Heule, P.J. Caspers, D.P. Hayes, M.H.A. Neumann, G.J. Puppels, Discriminating basal cell carcinoma from its surrounding tissue by raman spectroscopy, Journal of Investigative Dermatology, 119, 64-69 (2002).

9. S. Verrier, I. Notingher, J.M. Polak, L.L. Hench, In situ monitoring of cell death using raman spectroscopy, Biopolymers (Biospectroscopy), 74, 157-162 (2004).

10. I. Notingher, S. Verrier, S. Haque, J.M. Polak, L.L. Hench, Spectroscopic study of human lung epithelial cells (A549) in culture: living cells versus dead cells, Biopolymers (Biospectroscopy), 72, 230-240, 2003.

11. A. Synystya, et al, Raman spectroscopy of tissue samples irradiated by protons, Int. J. Radiat. Biol., 80(8), 581-591 (2004).

12. S.P. Verma, and A. Rastogi, Role of protein in protection against radiation-induced damage in membranes, Radiation Research 122, 130-136 (1990).

13. S.P. Verma, Low levels of irradiation modify lipid domains in model membranes: a laser Raman study, Radiation Research, 107(2), 183-193 (1986).

14. S.P. Verma et al, Ionising-radiation target groups of band-3 inserted into egg lecithin liposomes as determined by raman spectroscopy, International Journal of Radiation Biology, 63(3), 279-288 (1993).

15. R. J. Lakshmi, et al, Tissue Raman spectroscopy for the study of radiation damage: Brain irradiation of mice, Radiation Research, 157, 175-182 (2002).

11. K. Maquelin, C. Kirshner, L.P. Choo-Smith, N. van den Braak, H. P. Endtz, D. Naumann, G. J. Puppels, Identification of medically relevant microorganisms by vibrational spectroscopy, Journal of Microbiological Methods, 51, 255-271 (2002).

15. M.R. Slaughter, P.J. Bugelski and P.J. O' Brien, Evaluation of Alamar Blue reduction for the invitro assay of hepatocyte toxicity, Toxicology In Vitro, 13, 567-569 (1999).

16. V.R. Dayeh, S.L. Chow, K. Schirmer, D.H. Lynn, N.C Bols, Evaluating the toxicology of Triton X100 to protozoan, fish, and mammalian cells using fluorescent dyes as indicators of cell viability, Ecotoxicology and Environmental Safety, 57, 375-382, 2004.

17. E.J. Hall, Radiobiology for the Radiologist, Fifth Edition, Lippincott Williams and Wilkins (2000).

18. K. Ramser, E.J. Bjerneld, C. Fant, M. Kall, Importance of substrate and photo-induced effects in Raman spectroscopy of single functional erythrocytes, Journal of Biomedical Optics, 8(2), 173-178 (2003).

19. G.J. Puppels, J.H.M. Olminkhof, G.M.J. Segers-Nolten, C. Otto, F.F.M. de Mul, J. Greve, Laser irradiation and Raman spectroscopy of single living cells and chromosomes: sample degradation occurs with $514.5 \mathrm{~nm}$ but not with $660 \mathrm{~nm}$ light, Experimental Cell Research, 195, 361-367 (1991).

20. H.U. Gremlich and B. Yan eds, Infrared and Raman Spectroscopy of Biological Materials, Marcel Dekker (2000).

22. E. Ó Faoláin, M.B. Hunter, J.M. Byrne, P. Kelehan, H.J. Byrne, F.M. Lyng, A study examining the effects of tissue processing on human tissue sections using vibrational spectroscopy, Journal of Vibrational Spectroscopy, in press 